\title{
7 ombining soft power with the geopolitical approach - how difficult is for the EU to change its attitude?
}

\section{Radu Carp}

University of Bucharest, radu.carp (at) fspub.unibuc.ro

\begin{abstract}
Rezumat

After gradually evolving from an economic project to a political one, European Union leaders declare nowadays that it is time to go forward and to build a geopolitical actor on the international stage. This paper does make an account on the current stage of relevant geopolitical actors and how they view EU. In order to address this issue, EU have to focus more on its soft power instruments, like multilateralism and the promotion of democracy, rule of law and human rights, and also climate change, apart from hard power instruments like trade, security and defense, cybersecurity and data privacy.

După ce au evoluat treptat de la un proiect economic la unul politic, liderii Uniunii Europene declară în zilele noastre că este timpul să mergem mai departe și să construim un actor geopolitic pe scena internațională. Această lucrare face o prezentare a stadiului actual al actorilor geopolitici relevanți și a modului în care aceștia privesc UE. Pentru a aborda această problemă, UE trebuie să se concentreze mai mult pe instrumentele sale de soft power, cum ar fi multilateralismul și promovarea democrației, statului de drept și a drepturilor omului, precum și schimbările climatice, în afară de instrumentele de hard power precum comerțul, securitatea și apărarea., securitatea cibernetică și confidențialitatea datelor personale.
\end{abstract}

Keywords: democracy; European Union; geopolitics; human rights; multilateralism; rule of law; soft power

\section{BY-SA License (https://creativecommons.org/licenses/by-sa/2.0)}

This paper has been presented at the Eleventh International Conference on Baltic and Nordic Studies in Romania: ReThinking Europe in Scandinavia and the Baltic Sea region, hosted by the Romanian Association for Baltic and Nordic Studies, May 28-29, 2020.

New European leaders entered into office in the last months of 2019, after the European elections and a long process of negotiating the top positions. Not surprisingly, they underlined the need of the EU to act as a geopolitical player. Ursula von der Leyen spoke about the need to use the 
language of power ${ }^{1}$, Josep Borrell discuss about the geopolitical approach ${ }^{2}$. National leaders as Emmanuel Macron are discussing more in favor of Europe as a key actor on the international arena.

To focus or not on geopolitics is an issue that is widely discussed across key policy - makers since the emergence of the European Communities. The Founding Fathers chose to create and consolidate a single market, but the idea of acting in a powerful way in the international arena was never abandoned. In the 1990s and after 2000 the Yugoslav wars and the US intervention in Iraq have created new premises in order to restart the whole discussion on solid ground.

The first step towards the purpose of the EU to act as a geopolitical actor was made with the adoption of the European Security Strategy in $2003^{3}$. EU have been confronted since them with a lot of external challenges, from the war in Georgia in 2008, the Crimea issue in 2014, the global financial crisis, the migration crisis and the long-term international consequences of Brexit. For not many of these events, EU was not prepared. The instruments were not really fit to the purpose. Meanwhile, US, China, Russia but also emergent powers like Turkey and Iran realized that they have to be more involved in terms of power on the international arena and all of them increasingly sees EU not as a partner but as a competitor.

In order to achieve its geopolitical ambitions, EU have to choose the right way forward. It can act through economic instruments, like imposing its own product standards, be active in the WTO or impose more restrictive rules on competition policy to private entities registered in third countries willing to have access to the European market. The second way is to act as a

1 See Etienne Bassot, The von der Leyen Commission's priorities for 2019 - 2024, https://www.europarl.europa.eu/RegData/etudes/BRIE/2020/646148/EPRS BRI(2020)646148

EN.pdf. In her statements to the European Parliament in July and November 2019, as candidate for European Commission President and President-elect respectively, Ursula von der Leyen outlined the six political priorities that would shape the working programme of the European Commission. She has pledged to lead a "geopolitical Commission".

${ }^{2}$ Josep Borrell wrote that "to avoid being the losers in today's US-China competition, we must relearn the language of power and conceive of Europe as a top-tier geostrategic actor" (Embracing Europe's power, www.neweurope.eu).

${ }^{3}$ About this document, see Alison J.K. Bayles, The European Security Strategy: An Evolutionary History, SIPRI Policy Paper, No. 190/2005. 
multilateral organization that emphasize its soft power in order to address key international issues.

However, there is one very important, decisive prerequisite in order to act as a geopolitical actor: the willingness of the EU Member States to abandon their traditional national way of doing diplomacy. A single, strong foreign policy promoted by the EU means a step forward towards federalism and not all the Member States are prepared to accept such an outcome.

The perception of other international actors is that the EU is missing from the international arena. Many of the authors that wrote about the role of the EU discuss the need to counterbalance the influence of the US and there is a clear demand for a more assertive approach. The pandemics crisis has shown that, when it is confronted with a global crisis, the EU may react in an appropriate way, better than other international actors but nevertheless it takes time to find the best way.

But what exactly is understood by the need of more Europe? Russia wants a powerful EU because it hopes that the EU will abandon its alignment with the US and it will therefore weaken the transatlantic cooperation. This is a wrong perception, since in terms of human rights the EU is even more willing to show a strong stance towards Russia than the US. The recent Navalny affairs show that the EU acts in a paradoxical way: it can go forward with economic projects where Russia is a partner but meanwhile it will defend in a standard way the respect of human rights by Russia ${ }^{4}$. This paradoxical way of acting is of course subject to many controversies inside the EU itself but it is a good indicator on how the EU will act in the near future as a geopolitical player: combining both perspectives that we have described, economical and political. China wants a stronger EU for a different reason, in order to react to the aggressive US trade policy. For China, with the EU issues like climate change, 5G networks or fighting the

\footnotetext{
${ }^{4}$ How to deal with Navalny affair is a matter of public debate in Germany. Angela Merkel is facing growing pressure to toughen her stance toward Russia to abandon the Nord Stream 2 project, an underwater Baltic Sea pipeline nearing completion that would bring gas from Russia to Germany. See Pressure Grows For Merkel To Reconsider Germany-Russia Pipeline After Navalny Poisoning, https://www.rferl.org/a/west-mulls-response-after-germany-says-nerveagent-used-to-poison-russian-opposition-leader-aleksei-navalny/30818079.html.
} 
consequences of the pandemics are more easily to discuss with the EU than with the US. The strong commitment of the EU as regards human rights is not in the interest of China. As with Russia, EU is building its relationship with China in a paradoxical way: while completely dedicated to the respect of human rights in China, the EU is building strong economic ties with China. The relationship with the US is the most complicated in this international puzzle: about this relationship there is a strong internal divide in the US. The current Trump administration is looking at Europe as a competitor in solving international issues like Iran, Middle East or, more recently Kosovo, while it maintains a strong relationship with some EU Member States that are considered to put US first in their own strategy than the fact of belonging to the EU. On the other hand, there are clear signs of a EU willingness to emancipate from the US, in order to build itself the geopolitical capacities. Nevertheless, the common values of democracy and respect of human rights are stronger than the differences of approaches in some major international issues.

In order to become a key international actor that use geopolitics, EU have to rely on a key value - multilateralism ${ }^{5}$. This is the best way EU has acted until now on the international arena and some key developments were made. Of course, the bilateral stance is still widely used by the Member States bu in most of the cases it does not contradict what the EU decided to take as a multilateral approach. Member States undermining what the EU is doing in terms of foreign policy is still a practice but it constantly decreased from the moment when they realized the advantage of a common action. In many circumstances, Member States are waiting sometimes for a decision in Brussels and only then they are building their own decisions back home.

Is it multilateralism outdated? We see a lot of international organizations unable to engage in international conflicts (Syria) or somehow irrelevant and not meeting the high expectations of states (WHO since the start of the pandemics). If we take into account how all the international

\footnotetext{
${ }^{5}$ The European Council promotes multilateralism in the external action as an official policy since it adopted in June 2019 a document called EU action to strengthen rules-based multilateralism, Brussels. 10341/19, https://data.consilium.europa.eu/doc/document/ST-103412019-INIT/en/pdf.
} 
organizations have reacted to some crisis around the world, we can conclude that the EU have reacted in the best way, as compared to these organizations. Therefore, multilateralism does not need to be criticized only because some organizations are behaving better than others. Multilateralism is an advantage that the EU need to emphasize better. It depends a lot on the success of its current and future involvements. Multilateralism is a clear strength of the EU. By increasing this way of acting, the EU will become a stronger actor on the international arena.

EU is behaving like an international actor based on democracy, rule of law and human rights. The standards that the EU is using in these areas are higher than any other international standards used by other international actors, including the US. This is the result of a long bilateral involvement of some Member States. Denmark and Sweden are leading the way in promoting financial assistance worldwide based on human rights. EU borrowed this experience and have developed its own instruments. Humanitarian assistance is provided by Member States, by using the framework and guidelines of the EU. Rule of law mechanisms were tested within the framework of Association Agreements with third countries ${ }^{6}$ and the EU does have right now the most complex system in the world in order to assess rule of law. EU is providing assistance in terms of conflict resolution, mediation, transition to democracy in many parts of the world. By far, EU is the international actor that is the most involved in these issues. This soft power can be used as an argument to increase its capacity as an international actor. Important questions could be raised in this context. Do the EU will succeed in order to impose its own model of good governance, or third countries will still see democracy requirements as technical issues that can be adapted without a broad discussion in their societies? How far the Western model in general can be imposed without a major change that would affect its nature? As a soft power, EU can address all these challenges.

\footnotetext{
${ }^{6}$ For an analysis on the impact of rule of law requirements in the relationship with the Eastern Partnership countries, see Corina Rebegea, Rule of law after a decade of Eastern Partnership. Let's talk political change!, https://www.global-focus.eu/2019/08/rule-law-decade-eastern-partnership-lets-talkpolitical-changel.
} 
Climate change is another important indicator for determining if EU is or could be a global actor ${ }^{7}$. The current European Commission is very determined to invest in order to tackle climate change. Member States do cooperate very strong in this area. China, Russia and the US does not seem to take into account very much climate change as an issue that could reinforce their status in the world and do not see it as a strategic advantage. It is very clear that the EU cannot tackle climate change on its own. For that purpose, it is necessary to have international cooperation. The EU does have the legitimacy to act in this area, to propose and impose specific standards, based on Member States best practices.

To transform itself into a global actor, EU shall use better its role in the global trade. US is not willing to engage as it does in this area, therefore it could be the EU opportunity to replace it. There are however big challenges that the EU will confront if it chose to engage more on this path. EU Member States have divided opinions about the Belt and Road Initiative of China ${ }^{8}$. There is no single perspective on this issue in Brussels - in fact, this infrastructure initiative has as purpose not only to show the financial strength of China but also its capacity to act as a global actor and to win the battles with other global actors. The same with NordStream 2 project, where there is no consensus among Member States - this project is designed by Russia not only as an economic project but also to show that a global actor like the EU is dependent, at least in part to another global actor that is Russia. As regards global trade, EU have to work with clear and democratic accountable standards and to negotiate with other global actors based exclusively on these standards.

Another area of intervention for the EU as a global actor is security and defense. In terms of hard security, EU is lagging behind other global actors. European defense is still relying on NATO capabilities. Important

\footnotetext{
${ }^{7}$ On climate change policy as part of EU actions, see Andrew Jordan, Dave Huitema, Harro van Asselt, Tim Rayner, Frans Berkhout (eds.), Climate change policy in the European Union. Confronting the Dilemmas of Mitigation and Adaptation? (Cambridge: Cambridge University Press, 2010).

${ }^{8}$ For a detailed account on how the EU reacted to this initiative, see, Svante E. Cornell, Niklas Swanström, Compatible Interests? The EU and China's Belt and Road Initiative, SIPRI Report No. $1 / 2020$.
} 
steps were made in order to increase the EU profile in terms of security and defense matters. France vision for the EU emphasize the need to increase the profile as a hard power. Apart from increasing the budget dedicated to defense and security, EU can be further involved in a lot of issues thar could increase its profile. US retired in 2019 from the Intermediate - Range Nuclear Forces (INF) Treaty, but no other global actor shown its intention to replace it. The EU could address this issue in a more determined way, arguing why is important to have a role in this matter'.

There is also a need to adapt its strategy doctrine to the expectations of a global actor. Right now, having a strategy is a very important step forward but it is necessary to think more about adapting the content to how a global actor shall act.

Another area of acting like a global actor is cybersecurity and data privacy. It is an area where the EU does also have a strategic advantage. The General Data Protection Directive ${ }^{10}$ and the Network and Information Systems Directive are imposing very high standards. Other states around the globe have to adapt their behavior if they wish to be on the EU internal market. The current situation is nevertheless not seen as an advantage of acting like a global actor. The EU have to explain why this level of protection could be in the benefit of other global actors and it shall start to provide technology for the states that might be interested. There is a vulnerability in terms of hard power, as few countries have national security agencies dealing with cybersecurity.

For its partners on the international arena, EU is still too complicate to understand. Its complex mechanisms and decision - making processes are considered to be a challenge for the actors that use hierarchical of power in internal and external affairs. This is the reason why the actors that are competing with the EU prefer to address individual Member States. Taking into account this context, Member States shall be more confident in the EU common foreign policy, even if sometimes they don't see the advantages of

\footnotetext{
9 There was no EU reaction to the demise of the INF Treaty. See Nick Witney, Nothing to see here. Europe and the INF Treaty, 5.08.2019, www.ecfr.eu.

${ }^{10}$ About GDPR, see Chris Jay Hoofnagle, Bart van der Sloot, Frederik Zudervaen Borgesius, 'The EU general data protection regulation: what is and what it means' Information $\mathcal{E}$ Communicatons Technology Law Journal 28, 1 (2019): 65 - 98.
} 
supporting and implementing Brussels decisions. EU shall explain more to the Member States the need of changing the paradigm and turn into a geopolitical player.

EU have to improve its strategic vision and it have to be more engaged in the current discussions about the future of its relationship with NATO, the current crisis in Belarus, the future of the Middle East or the Balkans, etc. Together with the Member States, EU have to develop a strategic vision that can be used in any context on the international stage.

The EU Global Strategy of 2016 is an important step in the process of transforming EU into a global actor. It is time to go forward. Promoting multilateralism and improving the use of democracy, human rights and rule of law every time a dialogue with a geopolitical actor is engaged are the key elements in order to achieve this result. 


\section{References:}

___ "Pressure Grows For Merkel To Reconsider Germany-Russia Pipeline After Navalny Poisoning", https://www.rferl.org/a/west-mullsresponse-after-germany-says-nerve-agent-used-to-poison-russianopposition-leader-aleksei-navalny/30818079.html

Bassot, Etienne. The von der Leyen Commission's priorities for 2019 - 2024, https://www.europarl.europa.eu/RegData/etudes/BRIE/2020/646148 /EPRS BRI(2020)646148 EN.pdf

Bayles, Alison J.K. The European Security Strategy: An Evolutionary History, SIPRI Policy Paper, No. 190/2005.

Borrell, Josep. "Embracing Europe's power", www.neweurope.eu

Cornell, Svante E., Niklas Swanström, Compatible Interests? The EU and China's Belt and Road Initiative, SIPRI Report No. 1/2020.

European Council, "EU action to strengthen rules-based multilateralism", Brussels. 10341/19,

https://data.consilium.europa.eu/doc/document/ST-10341-2019INIT/en/pdf

Hoofnagle, Chris Jay, Bart van der Sloot, Frederik Zudervaen Borgesius, 'The EU general data protection regulation: what is and what it means' Information \& Communicatons Technology Law Journal 28, 1 (2019): 65 98.

Jordan, Andrew, Dave Huitema, Harro van Asselt, Tim Rayner, Frans Berkhout (eds.), Climate change policy in the European Union. Confronting the Dilemmas of Mitigation and Adaptation? (Cambridge: Cambridge University Press, 2010).

Rebegea, Corina. "Rule of law after a decade of Eastern Partnership. Let's talk political change!", https://www.global-focus.eu/2019/08/rulelaw-decade-eastern-partnership-lets-talk-political-change/

Witney, Nick. "Nothing to see here. Europe and the INF Treaty", 5.08.2019, www.ecfr.eu 